Automation and Utopia 



\section{Automation and Utopia}

\section{Human Flourishing}

in a World without Work

John Danaher

II Harvard University Press

Cambridge, Massachusetts, and London, England 2019 
Copyright $\odot 2019$ by the President and Fellows of Harvard College All rights reserved

Printed in the United States of America

First printing

Jacket design: Graciela Galup

Jacket art: Westend61/Getty Images

9780674983403 (EPUB)

9780674242210 (MOBI)

9780674242203 (PDF)

The Library of Congress has cataloged the printed edition as follows:

Names: Danaher, John, author.

Title: Automation and utopia : human flourishing in a world without work / John Danaher.

Description: Cambridge, Massachusetts : Harvard University Press, 2019. | Includes bibliographical references and index.

Identifiers: LCCN 2019010210 | ISBN 9780674984240 (hardcover : alk. paper)

Subjects: LCSH: Utopias. | Technological unemployment. | Quality of life. |

Human security. | Forecasting. | Human-robot interaction.

Classification: LCC HX806 .D35 2019 | DDC 335/.02-dc23

LC record available at https://lccn.loc.gov/2019010210 
This book is dedicated to the memory of my sister Sarah (1974-2018) - someone who was not afraid to dream of a better world, and who worked every day to make it a reality 
